\title{
TVORNICA RAVE U OZRAČJU POČETAKA KEMIJSKO-FARMACEUTSKE PROIZVODNJE NA PODRUČJU HRVATSKE
}

\author{
RAVE FACTORY AT THE BEGINNING \\ OF CHEMICAL-PHARMACEUTICAL \\ PRODUCTION ERA IN CROATIA
}

\author{
Stella Fatović-Ferenčić", Jasenka Ferber Bogdan**
}

\begin{abstract}
SAŽETAK
U radu je prikazan razvoj $i$ poslovanje kemijsko-farmaceutske tvornice Rave d.d. osnovane 1922. u Zagrebu. Na temelju arhivske i građevinske dokumentacije, stručnih i dnevnih glasila te promotivnog materijala rekonstruiran je smještaj tvorničkog kompleksa u zagrebačkoj industrijskoj zoni, prezentirane su njezine marketinške strategije i utjecaj na razvoj domaće proizvodnje lijekova i higijensko-sanitarnih potrepština. Kao važan motiv svoga poslovanja tvornica je isticala osamostaljivanje Rave kao domaće industrije od tada dominirajuće strane industrije, nacionalna obilježja svoga poslovanja te promicanje suradnje s mladom domaćom industrijom. $U$ skladu s tim Rave d.d. sudjeluje u izgradnji i razvoju domaće farmaceutske proizvodnje i domaćeg tržišta, poticanju razvoja suvremene industrije i borbi za povoljnije uvjete svoga poslovanja. Njezina je do sada neistražena povijest značajan segment početaka farmaceutske proizvodnje, ali istodobno i prilog poznavanju početaka poduzetništva na našim prostorima kao nezaobilaznog elementa u podizanju svijesti o nacionalnoj proizvodnji, razvoju i identitetu.
\end{abstract}

Ključne riječi: Rave d.d., farmaceutska industrija, industrijska baština, 20. stoljeće, Hrvatska

* Odsjek za povijest medicinskih znanosti Zavoda za povijest i filozofiju znanosti, Hrvatska akademija znanosti i umjetnosti.

** Arhiv za likovne umjetnosti, Hrvatska akademija znanosti i umjetnosti, Zagreb, Hrvatska. Adresa za dopisivanje: Jasenka Ferber Bogdan, Arhiv za likovne umjetnosti, Hrvatska akademija znanosti i umjetnosti, Gundulićeva ulica 24, 10000 Zagreb, Hrvatska. ORCID ID: https://orcid.org/0000-0002-9889-6479. E-pošta: jfb@hazu.hr. 


\section{UvoD}

Zamah farmaceutske industrije na području Hrvatske počinje istom nakon Prvoga svjetskog rata kada ljekarnici zbog nepovoljnih ratnih i poratnih okolnosti sve teže svladavaju probleme vezane uz iznimnu skupoću uvozne robe i poskupljenje ljekarničkih potrepština te se nerijetko nalaze na rubu materijalne propasti. ${ }^{1}$ Nagli razvoj farmaceutske industrije u ovom razdoblju povezan je i s ranim otvaranjem studija farmacije na zagrebačkom Sveučilištu (I882.), odnosno razvojem znanstvene farmacije čiji su začetnici farmaceuti Gustav Janaček i Julije Domac.

Već sredinom I9I8. osnovano je Dioničko društvo za industriju i promet droga i kemikalija Isis d.d., a slijedile su ga i druge farmaceutsko-kemijske tvrtke poput Kaštela d.d., Jugofarmacije d.d., Rave d.d. i Kemike d.d. Neke od njih osnovane su odmah kao dioničko društvo, primjerice tvornica Kaštel d.d. - preteča Plive. ${ }^{2}$ Neke su se, poput tvornice Rave čiju historiografiju donosimo u ovom radu, razvile iz laboratorija i drogerija, koji su prethodno bili vezani uz ljekarnu.

Unatoč intenzivnom razvoju farmaceutske industrije, osobito u međuratnom razdoblju, radovi posvećeni ovoj tematici iznimno su rijetki. ${ }^{3} \mathrm{Na}$ neprivlačnost industrijske baštine kao istraživačke teme na području Hrvatske osvrće se i Ivana Žebec Šilj navodeći: Industrijska povijest, iako u Hrvatskoj slabo obrađena, u međunarodnim je okvirima već znatno dulje prisutna tema. Aktualna ekonomska historiografija usmjerena je na razdoblje socijalizma, no da bi se razumjelo socijalističku industrijalizaciju u hrvatskom, a pogotovo u zagrebačkom

1 Uredništvo (1929), Predgovor Industrijskom broju, Farmaceutski vjesnik, 19 (poseban broj), $1-3$.

2 Tvornicu Kaštel osnovala su poduzeća Isis d.d. i Chinoin d.d. 1920., a s radom je započela sljedeće, 1921. godine.

3 Iako je zanimanje stručne i znanstvene javnosti za industrijsku baštinu, odnosno industrijsku arheologiju, u Hrvatskoj prisutno još od 1980-ih, ova se tema sustavnije istražuje tek posljednjih petnaestak godina. $U$ fokusu su posebno gradovi s razvijenijom industrijskom baštinom (Zagreb, Rijeka), u kojima je održan niz izložaba ove tematike. Zagrebačkom se industrijskom baštinom u razdoblju od 2009. do 2014. bavio projekt Gorana Arčabića, kustosa Muzeja grada Zagreba, pod nazivom Zagrebačka industrijska baština: povijest, stanje, perspektive, koji je upozorio na neistraženost toga zanemarenog segmenta kulturne baštine. U sklopu projekta održano je i nekoliko izložaba u Muzeju grada Zagreba: 2010. - Modernizacija na periferiji Carstva: zagrebačka industrijska baština 1862. - 1918., 2012. Industrijski centar države: zagrebačka industrijska baština 1918. - 1945. i 2016./2017. - Vrijeme giganata. Prva sinteza graditeljske industrijske baštine Rijeke prikazana je u knjizi R.I.P. riječka industrijska priča (Aničić, Ema (2014). R.I.P. - riječka industrijska priča. Rijeka; Muzej grada Rijeke). 
slučaju, potrebno je, smatram, prvo usvojiti gradivo iz međuratnog razdoblja. Za veći dio industrijske proizvodne djelatnosti, naime, temelji su položeni upravo tada. ${ }^{4}$

Oskudna historiografija farmaceutske industrije na području Hrvatske potvrđuje navedeno. Iznimku čini dobro dokumentirana povijest tvornice Kaštel d.d., preteče današnje Plive, ${ }^{5}$ te historiografija tvornice Alga o kojoj je prikazan razvoj u sklopu izložbe i pratećeg kataloga. ${ }^{6} \mathrm{O}$ nizu drugih novoosnovanih kemijsko-farmaceutskih tvrtki koje se osnivaju i djeluju u međuratnom razdoblju nema cjelovitih studija.

U ovom radu iznijet ćemo podatke o osnutku i radu kemijsko-farmaceutske tvornice Rave d.d., osnovane u Zagrebu i922. godine. Na temelju arhivske dokumentacije, stručnih i dnevnih glasila te promotivnog materijala rekonstruirat ćemo njezin razvojni put od laboratorija do njezine nacionalizacije I947. godine. Prema postojećoj građevinskoj dokumentaciji i objavljivanim oglasima identificirat ćemo smještaj pogona te pratiti njezina nastojanja u podizanju vlastite zgrade, što je jedan od najvažnijih elemenata rasta proizvodnje. Prikazat ćemo smještaj tvorničkog kompleksa u industrijskoj zoni koja se početkom 20. stoljeća formira na istočnom rubu Zagreba. Prezentirat ćemo utjecaj društvenih i gospodarskih prilika u zemlji na pozicioniranje dioničkoga društva Rave na domaćem tržištu, opisati njezine marketinške strategije te utjecaj ove tvornice na poticanje i razvoj domaće proizvodnje lijekova i higijensko-sanitarnih potrepština.

4 Žebec Šilj, Ivana (2017). Zagrebačka industrija 1935. - 1939. u kontekstu međuratnog gospodarskog razdoblja. Zagreb; Institut Ivo Pilar, 10.

5 O povijesti Plive napisano je nekoliko monografija i više članaka, ponajprije vezanih uz njezine obljetnice: Anonimno (1941), Kaštel tvornica kemijsko-farmaceutskih proizvoda d.d. (prigodom 20. godišnjice opstanka), Medicus 3 (5), 246-7; Anonimno (1961), 40 godina, Saopćenja, 4 (5), 206-10; Baković, Vladimir (1971), Razvoj jugoslavenske farmaceutske industrije, Saopćenja, 14 (1), 53-8; Ščrbašić, Mira (1974), Tradicija se nastavlja - izazov budućnosti, u: Keros, Predrag ed., Zbornik liječnika Hrvatske 1874-1974, Zagreb: Zbor liječnika Hrvatske, 1974, 299-306; Baković,Vladimir (1981), Osvrt na značajne obljetnice u SOUR Pliva u 1981. godini, Saopćenja 27 (2), 171-81; Ćapeta, Antun ed., (1996), Povjesnica Plive, Zagreb: Pliva d.d. Uz izložbu Kaštel na vrhuncu, postavljenu2016. godine u Knjižnici HAZU objavljen je i katalog: Fatović-Ferenčić, Stella, Brkić Midžić, Silvija(2016). Kaštel na vrhuncu: oglašavanje i ambalaža lijekova tvornice Kaštel u Zagrebu 1930-ih i 1940-ih, Zagreb; HAZU, Hrvatski muzej medicine i farmacije. Daljnja razrada marketinških strategija ove tvornice objavljena je u člancima Fatović-Ferenčić, Stella, Brkić Midžić, Silvija (2018). Početci i strategije marketinga tvornice Kaštel d.d. (1920.-1945.), Medicus 27(2): 211-222. Klinar, Ivana, Kolumbić Lakoš, Adela, Kovačić, Dražen, Matrapazovski Kukuruzović, Mirjana (2018), SUMAMED 30 godina - Kako je počela promocija PLIVINA originalnog antibiotika?, Medicus 27(2), 223-230.

6 Trkulja, Milica (2008), Alga, u: Dubrović, Ervin ed., Reklama u Rijeci 1890 - 1940. Rijeka: Muzej grada Rijeke. 2008, 38-43. 


\section{Od ljekarne Salvatoru do laboratorija RaVE Zagreb}

U Zagrebu je I826. osnovana ljekarna Salvatoru, jedna od starijih i svakako prometnijih gradskih ljekarni. Koncesija joj je dodijeljena dopisom Gradskoga poglavarstva u Zagrebu od ıo. lipnja ı826., a njezin je prvi vlasnik bio ljekarnik Georg Agustin. Nakon 39 godina ljekarna 1865. prelazi u vlasništvo Sigismunda (Žige) Mittelbacha starijeg koji posao u ljekarni znatno unapređuje. Tome je pogodovao i razvitak Zagreba, ali i premještanje ljekarne u Dugu ulicu broj 3 (danas Radićeva ulica), u samo gradsko središte. Nakon 33-godišnjega staža u ljekarni Salvatoru Žiga Mittelbach stariji ı898. predaje vodstvo ljekarne svom sinu Žigi. Novi joj je vlasnik ubrzo pripojio i drogeriju te se počeo baviti i prodajom tehničkih kemikalija i svih artikala koji spadaju u struku, na veliko. Žiga Mittelbach mlađi svojim je umijećem ubrzo razvio posao pa je ljekarna Salvatoru postala jedna od najprometnijih u Zagrebu, a u njoj je radio i niz zaposlenika. Nakon njegove smrti i917. ljekarna prelazi u vlasništvo udovice, a u lipnju i9r8. zakupljuje ju poduzetni ljekarnički dvojac Stjepan Rac i Dragutin Vergles ${ }^{7}$ (slika ı.). Osim što su bili ista generacija, kolege na studiju u Zagrebu, dvojica ljekarnika postaju i suradnici u ljekarni Salvatoru te naposljetku i poslovni partneri u tvrtki Rave.

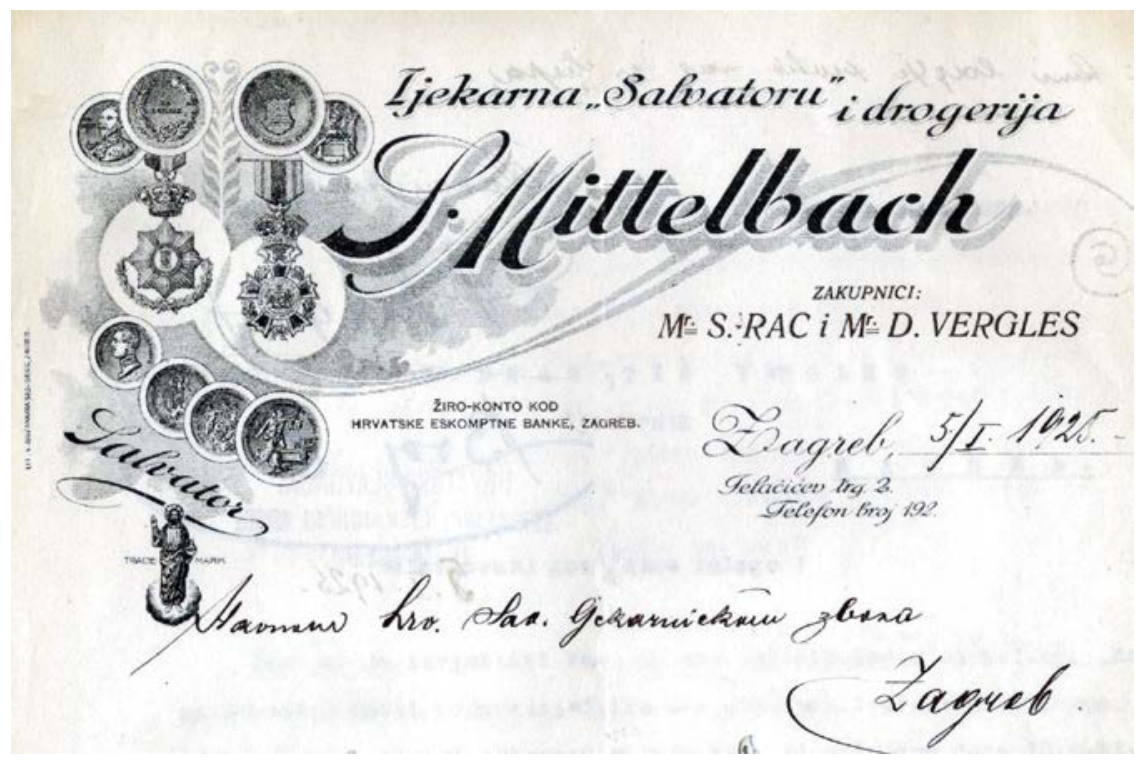

Slika r. Memorandum Ljekarne Salvatoru i drogerije Mittelbach u vrijeme zakupa mr. ph. Raca i Verglesa, I920-e. OPMZ-HAZU, Fond ljekarništvo/ Ljekarna Salvatoru

Anonimno (1926), Razne vijesti. Stota obljetnica ljekarne Salvatoru u Zagrebu, Vjesnik ljekarnika, 8, 616-17. 


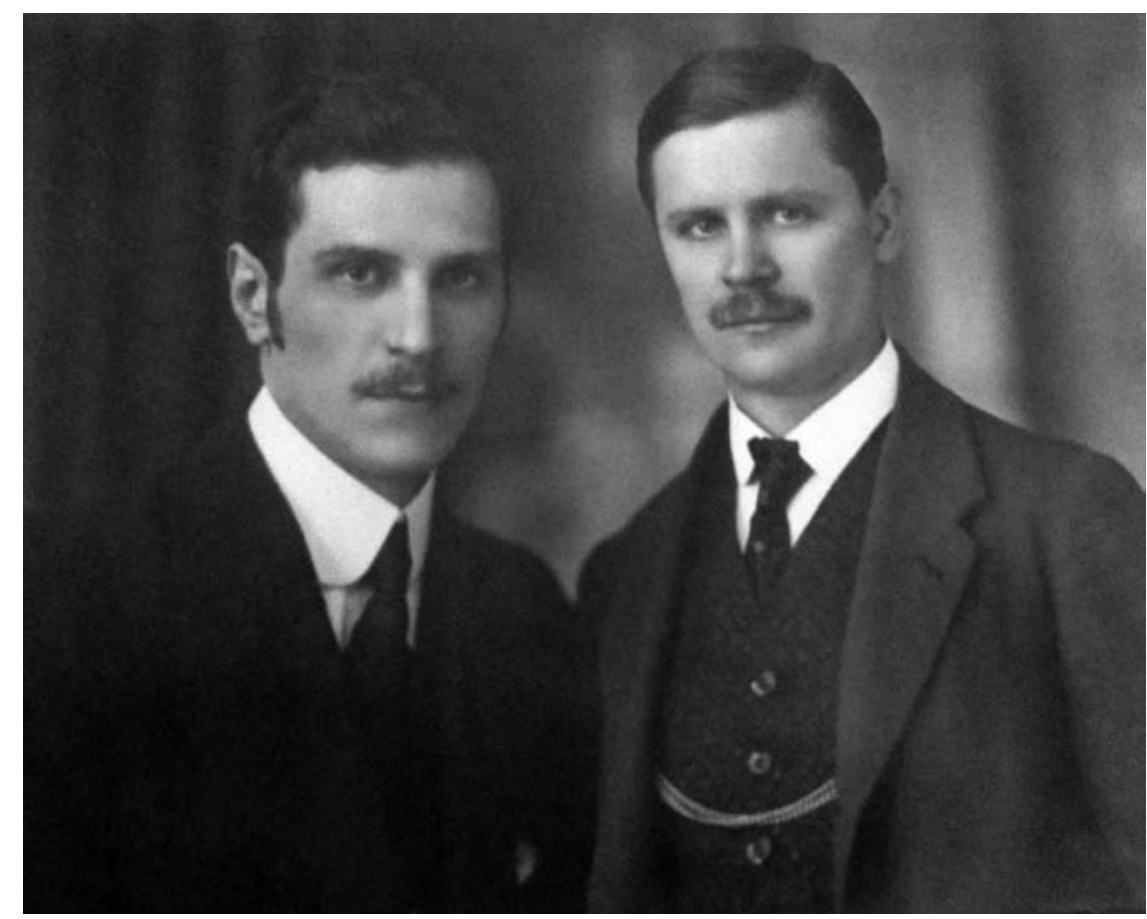

Slika 2. Ljekarnici Dragutin Vergles i Stjepan Rac. Iz fotoalbuma obitelji Rac

Sa svojim su obiteljima i stanovali na istoj adresi u vili u Mošinskijevoj ulici br. 32 (danas Nazorova ulica) ${ }^{8}$ (slika 2.).

Stjepan Rac rođen je u mjestu Sv. Ivan Zelina I889. godine. Ljekarnu Salvatoru dobro je upoznao s obzirom na to da je radio u njoj od svojih najranijih početaka, isprva kao praktikant (I906. - I909.), potom kao asistent, a rad nastavlja i tijekom studija na Farmaceutskom fakultetu u Zagrebu gdje je i diplomirao ıوı. godine. ${ }^{9}$ Nakon diplome Rac je u ljekarni zaposlen kao suradnik (I9II. - I9I7.), potom tek nekoliko mjeseci u razdoblju od 6. prosinca I9I7. do I9. lipnja I9I8. i kao njezin providnik. Zakupnik je ove ljekarne od 20. lipnja I9I8. do 3I. prosinca I929. godine. ${ }^{10}$

Dragutin Vergles rođen je u Zagrebu I889. godine. Praksu je obavljao u Bosanskoj Gradiški u od I906. do I909., a tirocinijski je ispit položio 25.

8 Za podatke o obitelji Rac zahvaljujemo unucima Stjepana Raca, Mladenu i Branimiru Racu.

9 Kujundžić, Nikola, (2012). Spomenica u povodu 130. obljetnice nastave farmacije 1882-2012. Zagreb; Farmaceutsko-biokemijski fakultet Sveučilišta u Zagrebu, 222.

10 OPMZ HAZU. Fond ljekarništvo/Ljekarna Salvatoru. Kartoteka ljekarnika: Mr. Stjepan Rac. 
srpnja 1909. godine. Studirao je na zagrebačkom Farmaceutskom fakultetu, na kojem je diplomirao I9ı. godine. ${ }^{11}$ Od kolovoza I9ı. do travnja I9ı3. radi kao magistar kod ljekarnika Bartulića u kaptolskoj ljekarni Sv. Marije. Nakon toga, od I9I3. do kraja I929., sa Stjepanom Racom radi u ljekarni Salvatoru Žige Mittelbacha mlađeg, koju i9ı8. zajedno zakupljuju. Od ı. siječnja ı930. dioničar je tvrtke Rave d.d., a kao potpredsjednik Hrvatskoga ljekarničkog zbora (I925.) surađivao je i na izradi prve jugoslavenske Taxe medikamentorum. ${ }^{12}$

Budući da su mogućnosti značajnije proizvodnje lijekova i specijaliteta isprobali već u vrijeme rada u laboratoriju kao zakupnici ljekarne Žige Mittelbacha i pridruženoj joj drogeriji, Rac i Vergles usmjeravaju svoj interes na proizvodnju specijaliteta i veletrgovinu. Već tada je njihova motivacija bila usmjerena osnutku samostalnog poduzeća za proizvodnju lijekova i kozmetike. ${ }^{13}$ Laboratorij Rave osnovan je stoga već I9I8. kada još obojica njegovih osnivača rade u ljekarni Salvatoru. U almanahu za farmaciju i kemiju Aesculap kemijsko-farmaceutski laboratorij Rave Zagreb oglašava se primjerice kao najmodernije uređeni laboratorij za ljekarničku industriju na veliko sa električnim pogonom. ${ }^{14}$

\section{OD LABORATORIJA DO DIONIČKOG DRUŠTVA}

Završetkom Prvoga svjetskog rata grad Zagreb od periferijskoga ugarskog dijela Habsburške Monarhije postaje jedan od trgovačkih i novčarskih središta novonastale države. U to vrijeme u Hrvatskoj se, kao i u ostalim novoosnovanim državama jugoistočne Europe, težilo razvoju neovisnih gospodarstava koja bi služila nacionalnim interesima. Taj cilj trebao se postići poticanjem domaćih investitora, zaštitom od konkurentske strane industrije i sveobuhvatnom industrijalizacijom zemlje. ${ }^{15}$ Nakon Prvoga svjetskog rata, osobito u razdoblju I920. - I923., dolazi do izrazite inflacije koja je prema stajalištu teoretičara društvene krize Johna Maynarda Keynesa dovela i do oporavka gospodarstva, stimulirajući poduzetništvo. ${ }^{16}$ Dok je, primjerice, u Jugoslaviji I9I8. poslovalo I83I poduzeće, već početkom I920-ih osnovana su

Kujundžić, N. (2012), 222.

2 OPMZ HAZU. Fond ljekarništvo/Ljekarna Salvatoru. Kartoteka ljekarnika: mr. Dragutin (Carol) Vergles

13 Anonimno (1929), „Rave“ Kemijsko-farmaceutsko industrijsko i trgovačko d.d., Zagreb, Farmaceutski vjesnik, 19 (industrijski broj), 48.

14 Reklama Rave laboratorija (1922). Aesculap almanah za farmaciju i kemiju, 2, bez paginacije.

15 Žebec Šilj, I. (2017), 26.

16 Žebec Šilj, I. (2017), 28. 
I262 nova. ${ }^{17}$ Ti su trendovi uočljivi i na razvoju farmaceutske industrije i na primjeru razvoja tvornice Rave.

Procijenivši pogodan gospodarski trenutak poduzetnički je dvojac Rac i Vergles krenuo tijekom I921. u proizvodnju farmaceutskih šećerića i čokolada pa svoj laboratorij I922. pretvaraju u dioničko društvo s glavnicom od 5.000 .000 kruna. $^{18}$

Prema zapisniku Utemeljiteljnoga arka za supskripciju iz I922. vidljivo je da je tvrtka Rave kemijsko, farmaceutsko, industrijsko i trgovačko dioničko društvo kojemu je svrha proizvodnja kemijsko-farmaceutskih i kozmetičkih proizvoda i ljekovitih šećerića te trgovina svih kemijskih i farmaceutskih proizvoda i potrepština. Naziv poduzeća Rave skovan je od dvaju početnih slova prezimena vlasnika $\mathrm{Ra}$ (c) i Ve(rgles), a njezino je sjedište uz Mittelbachovu ljekarnu u Dugoj ulici (danas Radićeva) na kućnom broju 3.

Konstituirajuća skupština ovog društva održana je 30. ožujka I922., a njezini su utemeljitelji ujedno i prvi dioničari. Temeljna dionička glavnica je j.k. 5.000 .000 razdijeljenih s 5000 komada dionica po rooo j.k. nominale, koje glase na donosnika. Stjepan Rac u to vrijeme posjeduje I350 dionica, Dragutin Vergles i Deziderius Hoff također I350, Josip Hoff 400, Leopold Glaninger 250, Arnold Hunski 250 te Artur Gvozdanović 50 dionica ${ }^{19}$. Ravnateljstvo dioničkog društva čine Stjepan Rac, ljekarnik, kao glavni ravnatelj i predsjednik ravnateljskog vijeća, Leopold Glaninger iz Beča te Desiderius Hoff i Arnold Hunski. Članovi Nadzornog odbora bili su Dragutin Vergles, ljekarnik, Josip Hoff, trgovac, i Artur Gvozdanović, ravnatelj Hrvatske eskomptne banke u Zagrebu ${ }^{20}$.

U to vrijeme važnost domaće kemijske i farmaceutske industrije neprestano se ističe. Uviđa se njezina uloga u razvoju gospodarstva zemlje pa tako taj aspekt proizvodnje postaje i tema akademskih predavanja, ${ }^{21}$ ali i promidžbenih filmova. ${ }^{22}$ Zagrebački zbor stoga, uz ostale sadržaje, otvara vrata i prezentaciji proizvoda pojedinih predstavnika kemijsko-farmaceutske industrije pa

Žebec Šilj, I. (2017), 28 - bilješka 33.

18 Anonimno (1922), Trgovačke i industrijalne vijesti. Rave kemijsko-farmaceutsko industrijsko i trgovačko D.D. Zagreb, Vjesnik ljekarnika, 4(3), 90-1.

19 HR-DAZG-940, Sudbeni stol u Zagrebu, Trgovački sud, Zb 37/22 kutija 2298, spis Utemeljiteljna osnova i arak za supskripciju.

20 Anonimno (1922), Trgovačke i industrijalne vijesti. Rave kemijsko-farmaceutsko industrijsko i trgovačko D.D. Zagreb, Vjesnik ljekarnika, 4(3), 90-1.

21 Anonimno (1922), Strukovne vijesti. Naša kemijska industrija i sirovine za nju, Vjesnik ljekarnika,4(4), 122-3.

22 Anonimno (1922), Prikazivanje Merckovog filma u Zagrebu, Vjesnik ljekarnika, 4 (12), $330-1$. 


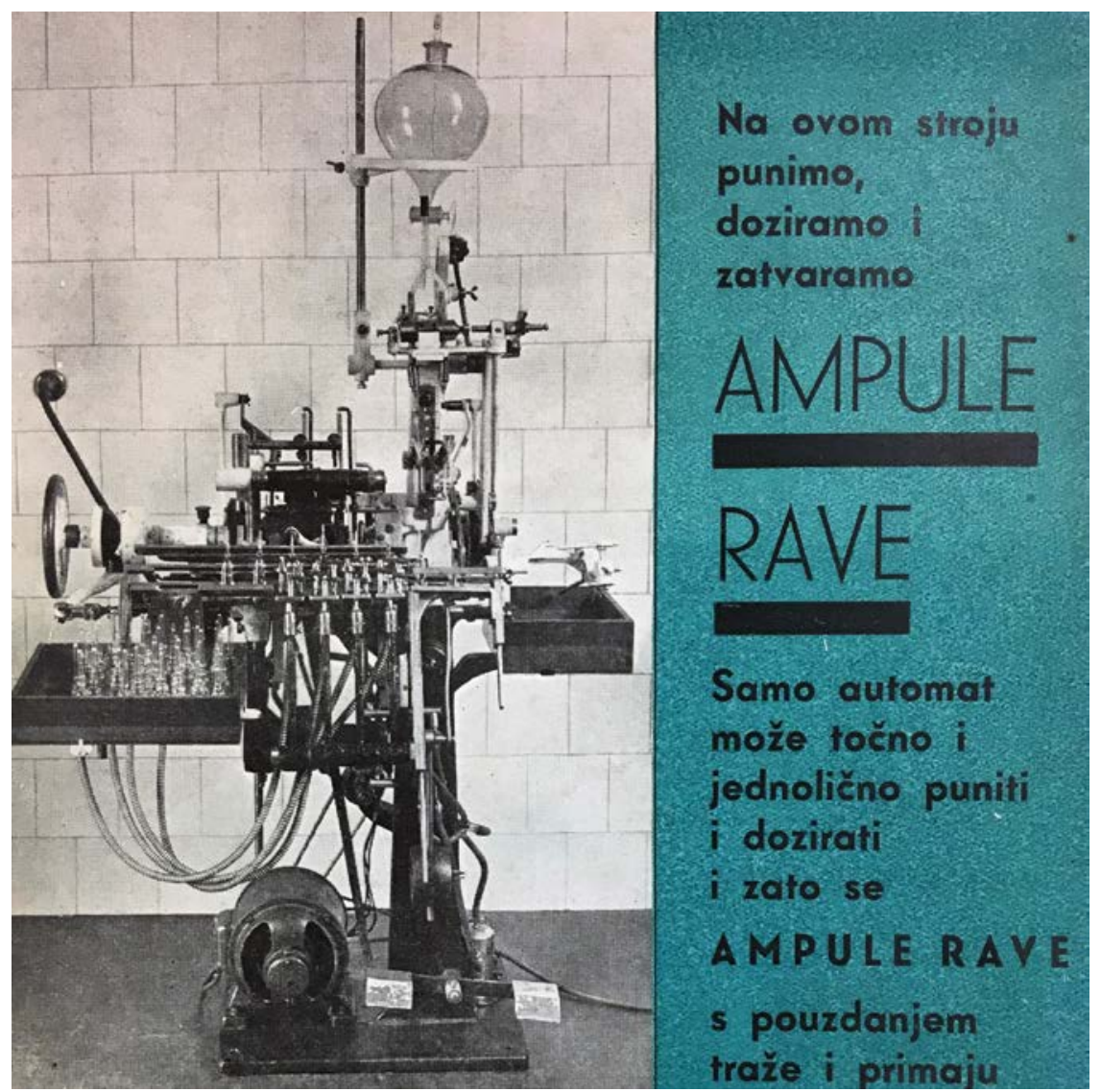

Slika 3. Reklama - stroj za ampule Rave, Medicinsko-farmaceutska pošta, 1935 .

ih ondje kao izlagače nalazimo već i922. godine. Dioničko društvo Rave već se tada predstavlja sa svojim proizvodima - od Sulfocol sirupa, Chinoferrola, Vinovice do kozmetičkih proizvoda, tableta, pasta, farmaceutskih šećerića itd. ${ }^{23}$ Iste godine na stranicama Vjesnika ljekarnika nalazimo i prvu reklamu novoosnovane tvrtke, ujedno i prve naše tvornice koja počinje s proizvodnjom ljekovitih šećerića. Entuzijazam i polet društva očituje se i u tome što je već I922. kupljeno i zemljište na kojemu se predviđa izgradnja tvorničke zgrade, a to je, kako se navodi u izvješću, velik korak $k$ riješenju problema proizvodnje. $^{24}$

23 N.I. (1922), Zagrebački zbor i farmaceutska industrija, Vjesnik ljekarnika, 4 (8), 231-234.

24 HR-DAZG-940, Sudbeni stol u Zagrebu. Trgovački sud, Zb 37/22 kutija 2298. Godišnje izvješće o poslovanju tvrtke, 13. ožujka 1923. 


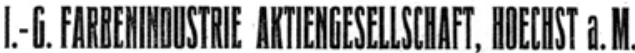

Preuzeli smo raspačavanje po

prof. dru Degkwitzu priredjeni

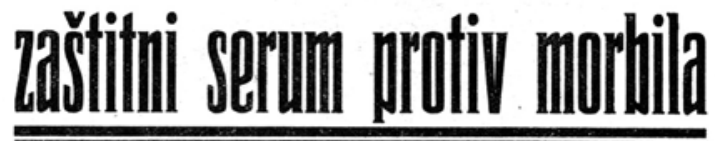

Ovaj serum imade svrhu, _da zaštiti zdravu djecu, koja još nijesu bila zaražena morbilima, od oboljenja, ako su u doticaju s oboljelima na dobracu.

Zaštitno djelovanje ovog seruma, koji je priredjen od ovaca, odredjuje prof. dr. Degkwitz, a naš zavod ispituje na uobičajeni način neškodliivost i sterilnost seruma, prije nego ga stavlja u promet

\section{1 ampula seruma sadržaje 1 zaštitnu jedinicu.}

1 zaštitna jedinica seruma je ona doza, koja se kod zdravog djeteta do 4 . godine najranije 7 . dana inkubacije primjenjuje, dakle 3 . dan nakon pojave egzantema kod inificiranog, oboljelog djeteta.

Originalni omoti: škatulje sa 1,10 i 25 ampula

Literaturu $\preccurlyeq$ alje na zahtjev:

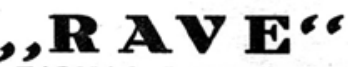

KEMIJSKO-FARMAC. I INDUSTRIJSKO D. D.

Z A $\mathbf{A}$ : $\mathbf{E} \quad \mathbf{B}$

M A ŻU R A N I Ć E TRG 3 .

$42-6$.

Slika 4. Reklama za zaštitni serum protiv morbila tvrtke I.G. Farbenindustrie. Liječnički vjesnik, I926.

Uz ljekarnu Salvatoru, koju su Rac i Vergles imali u zakupu, dvojica ljekarnika vode i drogeriju koja je isprva bila smještena uz ljekarnu na Jelačićevu trgu. Drogerije su još prema zakonskoj odredbi iz I9ıo. morale i lokacijski biti odijeljene od ljekarni pa Rac i Vergles I924. drogeriju premještaju na novu lokaciju u Ilici 6r. ${ }^{25}$

25 Anonimno (1924), Preseljenje drogerije, Vjesnik ljekarnika, 6(4), 160. 


\section{RAZVOJ PROIZVODNJE}

Već sljedeće, 1923. godine u izvješću se navodi da poslovanje novoosnovane tvrtke nije išlo prema očekivanjima. Velika stavka u izdacima odnosila se na troškove utemeljenja $i$ adaptacije zgrada koje su uz to tudje vlasništvo, postavljanje strojeva, instalacija elektrike, vodovoda $i$ plina, troškovi protokolacije $i$ silu drugih izdataka koji danas ne predstavljaju nikakovu imovnu čest, nego dati, nepovratni troškovi koji su se kao takovi morali uvrstiti u gubitak. ${ }^{26}$ Kao razlog lošijem poslovanju od očekivanog navode se loše prometne, carinske i financijske prilike zbog kojih se na unaprijed plaćenu uvezenu robu čeka tri-četiri mjeseca te spora isporuka naručenih strojeva i čekanje na njihovo postavljanje. Problemi vezani uz manjak prostora, zbog kojeg su neki strojevi ostali izvan pogona, i uz troškove najma s negativnim učinkom na efikasnost proizvodnje, iznose se već u prvim izvješćima tvrtke. ${ }^{27}$ Težilo se stoga izgradnji vlastite zgrade u kojoj bi se moglo u punom opsegu razviti produkciju. ${ }^{28} \mathrm{U}$ međuvremenu Rave d.d. kao svoju primarnu lokaciju, prema obrtnici izdanoj 1925., navodi Dugu ulicu na kućnom broju 3, sastanke dioničara i skupštine obavlja na adresi Jelačićev trg 2, a prema oglasima u tisku mogu se identificirati i adrese pojedinih skladišta, primjerice Marulićev trg 3 i Gajeva 32, dok se drogerija nalazi na adresi Ilica 6r.

Unatoč teškoćama oglasi proizvoda Rave d.d. prisutni su od samih početaka rada tvornice i u dnevnim tiskovinama. Primjerice, list Virovitičan oglašava Formosal kremu koja se rabi za otklanjanje neugodnog mirisa znoja, a može se kupiti u svim ljekarnama i drogerijama. ${ }^{29}$ Bili su to tek skromni početci oglašavanja ove tvornice koja će u sljedećem razdoblju intenzivnije strategije oglašavanja proizvoda razvijati postupno, ali vrlo razrađeno u različitim stručnim publikacijama. ${ }^{30}$

Rave d.d. na tržištu konkurira s nizom farmaceutskih specijaliteta, kao što su ekspektorans Sulfocol, roborans Chinoferrol, antigonoroikum Gonivan, nervni tonik Vacambrol, dijetetski adstringens Žirov Cacao i dr. Trgovački odjel dioničkog društva Rave, prethodno poznat pod imenom Pharma, bio je

26 HR-DAZG-940, Sudbeni stol u Zagrebu. Trgovački sud Zb 37/22 kutija 2298. Godišnje izvješće o poslovanju tvrtke, 13. ožujka 1923. godine.

27 HR-DAZG-940, Sudbeni stol u Zagrebu. Trgovački sud Zb 37/22 kutija 2298. Zapisnik II. redovite glavne skupštine, 2. ožujka 1924. godine.

28 HR-DAZG-940, Sudbeni stol u Zagrebu. Trgovački sud Zb 37/22 kutija 2298. Zapisnik II. redovite glavne skupštine, 2. ožujka 1924.

29 Reklama za Formosal (1923), Virovitičan, 40, 3.

30 Doneseni su propisi prema kojima je zabranjeno oglašavanje lijekova u dnevnom tisku. Usporedi: Anonimno (1926), Zabrana oglašavanja lijekova i farmaceutskih preparata, Vjesnik ljekarnika, 8, 42. 
također opskrbljen različitim artiklima, čime tvrtka krči put konkuriranja na tržištu robe za široku potrošnju. Uza sve poteškoće poslovalo se s dobitkom od 98.810.42 dinara, što je s obzirom na gospodarske i političke okolnosti, kako se navodi u izvješću za 1923. godinu, bio zadovoljavajući rezultat. ${ }^{31}$

Tijekom 1924. dolazi do jačanja domaće valute i porasta kupovne moći pa Rave d.d. nastoji što manje uvoziti, osobito sirovine za proizvodnju, a djelomično snižava i cijene svojih proizvoda. Gotovu robu nabavlja iz Češke, Italije, Francuske i Austrije te i za te artikle nastoji sniziti cijenu. Naručene sirovine iz Njemačke, međutim, znatno otežavaju posao jer zbog pada marke višestruko poskupljuju prije nego što stignu do dobavljača. Osobita pozornost posvećuje se marketingu preko posjeta liječnicima, a za promidžbene svrhe tvrtka u suradnji s tvrtkom Bayer $\mathcal{E}$ Co, zapošljava i jednog liječnika. ${ }^{32}$ Tvornica svoje proizvode predstavlja i na Medicinsko-farmaceutskoj izložbi na Zagrebačkom zboru, održanoj od 21. do 27. listopada 1924. godine. ${ }^{33}$ Iste godine izlazi i cjenik lijekova tvornice te pohvalni osvrt o tome u Vjesniku ljekarnika. ${ }^{34} \mathrm{U}$ cjeniku su navedene grupe artikala tvrtke: farmaceutski šećerići i čokolade u vlastitoj proizvodnji; farmaceutski specijaliteti (vlastiti i specijaliteti tvornica koje tvrtka zastupa); droge i kemikalije; kozmetički preparati od kojih su većina vlastiti proizvodi tvrtke; medicinski i toaletni sapuni; eterična ulja, kemijski proizvodi i boje tt. Schimme $\mathcal{E}$ Co., po čemu je Rave prva tvrtka koja se bavi ovom granom u tadašnjoj državi; gumena roba, sanitetski materijal; farmaceutske potrepštine; vage i utezi; fotografski aparati tt. Rietzschel München, te fotografski papir, filmovi i kemikalije, tt. Farbenfabriken vorm. Friedr. Bayer $\mathcal{E}$ Co. (slike 5. - 7.).

Iste je, 1924. godine, zbog nemogućnosti dobivanja građevinske dozvole, tvrtka prodala prethodno kupljeno gradilište..$^{35}$ Izgradnja vlastite zgrade u izvješćima ostaje stoga trajno isticana kao jedan od najvažnijih ciljeva tijekom sljedećih pet godina.

Tijekom 1925. dolazi do dodatnih povoljnih okolnosti za industriju, tj. uvođenja carinskih tarifa koje domaćoj industiji osiguravaju monopol na unutarnjem tržištu. Rave d.d. je 1925. poslovala s dobitkom od 108.322.95

31 HR-DAZG-940, Sudbeni stol u Zagrebu, Trgovački sud Zb 37/22 kutija 2298. Godišnje izvješće o poslovanju u 1924. godini, 22. veljače 1924.

32 HR-DAZG-940, Sudbeni stol u Zagrebu, Trgovački sud Zb 37/22 kutija 2298. Izvješće III. redovite glavne skupštine, 29. ožujka 1925.

33 Anonimno (1924), Medicinsko-farmaceutska izložba u Zagrebu, Vjesnik ljekarnika, 6, 495.

34 Anonimno (1924), Trgovačke vijesti. Novi cjenik, Vjesnik ljekarnika, 6, 395.

35 HR-DAZG-940, Sudbeni stol u Zagrebu, Trgovački sud Zb 37/22 kutija 2298. Izvješće s III. redovite glavne skupštine, 29. ožujka 1925. 


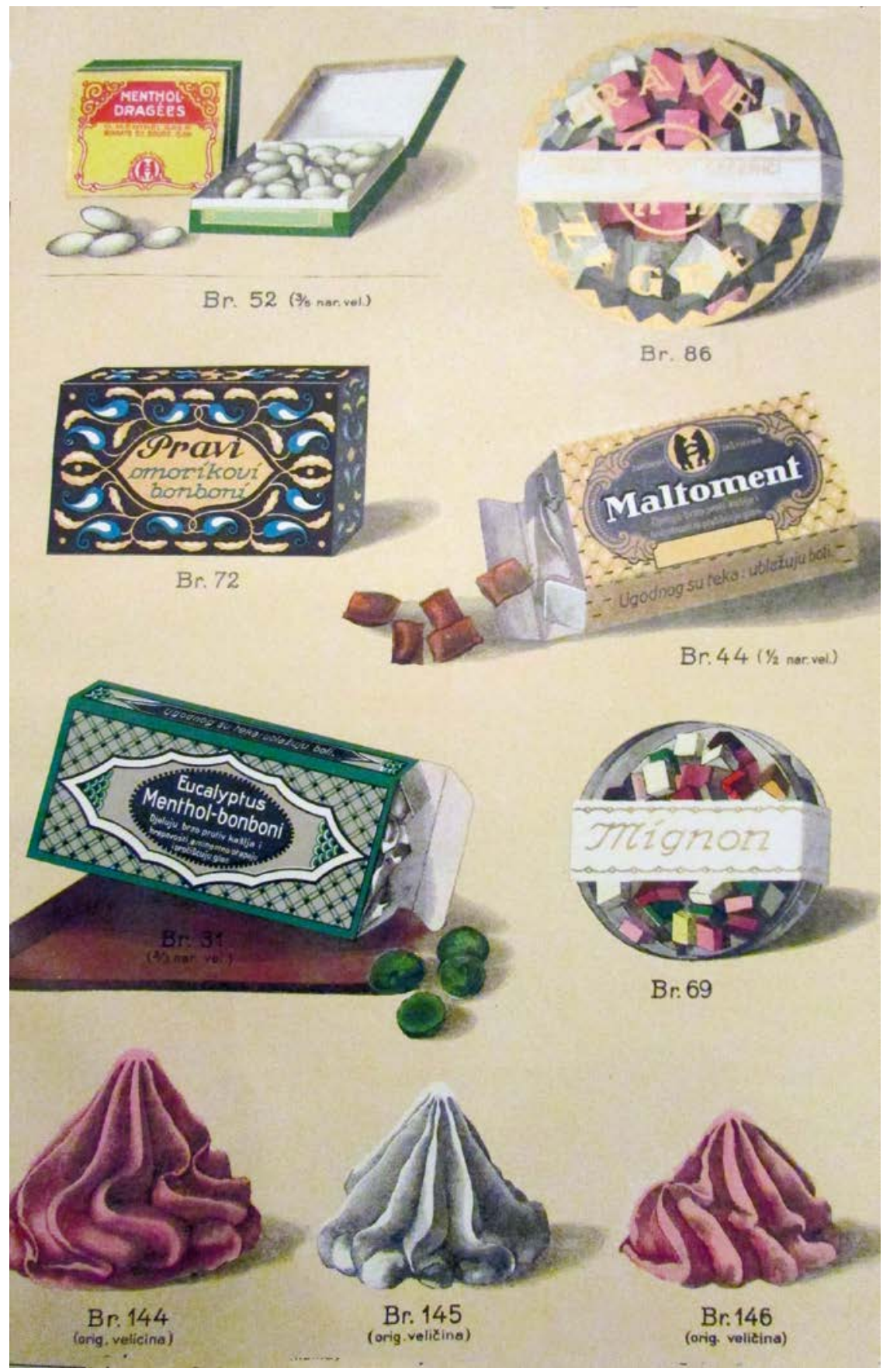

Slika 5. Reklama za Rave šećeriće. Publikacija Rave proizvoda 1924., vlasništvo obitelji Rac

dinara, a i sljedeća će godina rezultirati dobrim poslovnim uspjehom. Tome 
je pridonijela i činjenica da tvornica proširuje asortiman kozmetičkih i higijenskih proizvoda te postaje zastupnikom tada renomiranih svjetskih tvornica poput Schimmel Eु Co., Miltitz bei Leipzig; Vulkan Gummiwarenfabrik, Weis Eु Baessler Leipzig - Lindenau; ${ }^{36}$ Apotheke R. Höffer, Beč; EggerËComp. itd. ${ }^{37}$ Kada je I926. došlo do ujedinjenja svih zastupstava farmaceutskih odjela u Njemačkoj (Hoechst, Kalle, Cassella i Agfa) pod novim zajedničkim imenom L. G. Farbenindustrie A. G. Pharmaceutische Abteilung, Laverkusen, njihovo zastupstvo također prelazi u Rave. ${ }^{38}$ Stoga se u izvješću za I926. navodi: Poslovni promet društva u 1926. godini znatno je porastao tj. od Din. 3,525.735.52 u I925. god. na Din. 4,048.571.09 u ovoj godini. Ovaj 15\% porast prometa imamo da zahvalimo u prvom redu solidnom vodjenju poduzeća uslijed čega povjerenje prema našem društvu i broj mušterija neprestano raste, a u drugom redu proširenjem našeg odjela „zastupstva“ pridolaskom novih velikih njemačkih tvornica. ${ }^{39}$

Rave u svoju ponudu uvodi i sredstva za sunčanje, pudere za djecu i odrasle te pripravke poput čokoladnih tableta za probavu. Kako se proizvodnja farmaceutskih šećerića i čokolada pokazala profitabilnom, I926. proširuje svoju tvornicu novim odjelom ljepljivih i ljekovitih melema: I ovaj je projekt kao što se navodi u izvješću, pokrenut u cilju što veće emancipacije od inozemstva stvaranjem neovisne, nacijonalne industrije... ${ }^{40}$ (slika 6.). U tu svrhu nabavljen je novi stroj iz Beča čije je postavljanje stajalo 60.000 dinara. U r926. godini poslovalo se s dobrim uspjehom pa je dobit iznosila 152.4I2.20 dinara. Sljedeće, I927. i I928. godine poslovanje je bilo lošije pa je tvrtka svoje izvješće za I928. završila poslovnim gubitkom u iznosu od 97.4I4.45 dinara. Tome su znatno pridonijele režijske stavke koje su porasle na I.594.046.52, dakle za 306.618.49 dinara. Ovaj skok bio je rezultat povišenja poreza, većeg ulaganja u reklamu, povećanja putnih troškova te neutjerivog duga pojedinih klijenata (dug je kod ove stavke iznosio 63.I24.40. dinara). Za I928. godinu društvo stoga nije isplatilo dividendu, ni tantijeme ravnateljstvu i nadzornom odboru. ${ }^{41}$

\footnotetext{
36 Anonimno (1926), Razne vijesti. 40 godišnji jubileum tvornice gume Vulkan, Vjesnik ljekarnika, 8, 617.

37 Anonimno (1929), Rave Kemijsko-farmaceutsko industrijsko i trgovačko d.d., Zagreb, Farmaceutski vjesnik 19 (poseban broj), 48.

38 Anonimno (1929), Rave Kemijsko-farmaceutsko industrijsko i trgovačko d.d., Zagreb, Farmaceutski vjesnik 19 (poseban broj), 49.

39 HR-DAZG-940, Sudbeni stol u Zagrebu, Trgovački sud Zb 37/22 kutija 2298. Izvješće sa V. redovite glavne skupštine, 6. ožujka 1927.

40 HR-DAZG-940, Sudbeni stol u Zagrebu, Trgovački sud Zb 37/22 kutija 2298. Izvješće sa V. redovite glavne skupštine, 6. ožujka 1927.

41 HR-DAZG-940, Sudbeni stol u Zagrebu, Trgovački sud Zb 37/22 kutija 2298. Izvješće sa VII. redovite glavne skupštine, od 11. svibnja 1929.
} 
Poslovna godina I929. ipak donosi olakšanje i bolji uspjeh. Prema izvješću koje se donosi na Godišnjoj skupštini, navodi se da su političke okolnosti 6. siječnja I929. omogućile sređivanje političkih prilika u zemlji, što je rezultiralo porastom povjerenja inozemstva u domaće gospodarstvo. Posljedično je bilo lakše postići povoljne robne kredite kod inozemnih dobavljača. ${ }^{42}$ Promet je porastao za 5 posto. Tvrtka je napustila nerentabilno zastupstvo t.t. I. G. Farbenindustrie. Dobitak u I929. iznosio je II9.200.60 dinara, a rentabilitet uložene glavnice ıo posto, što je bio vrlo dobar uspjeh. Poduzeće je poslovalo bez duga. Posebna pozornost posvećivala se izgradnji što neovisnije domaće farmaceutske

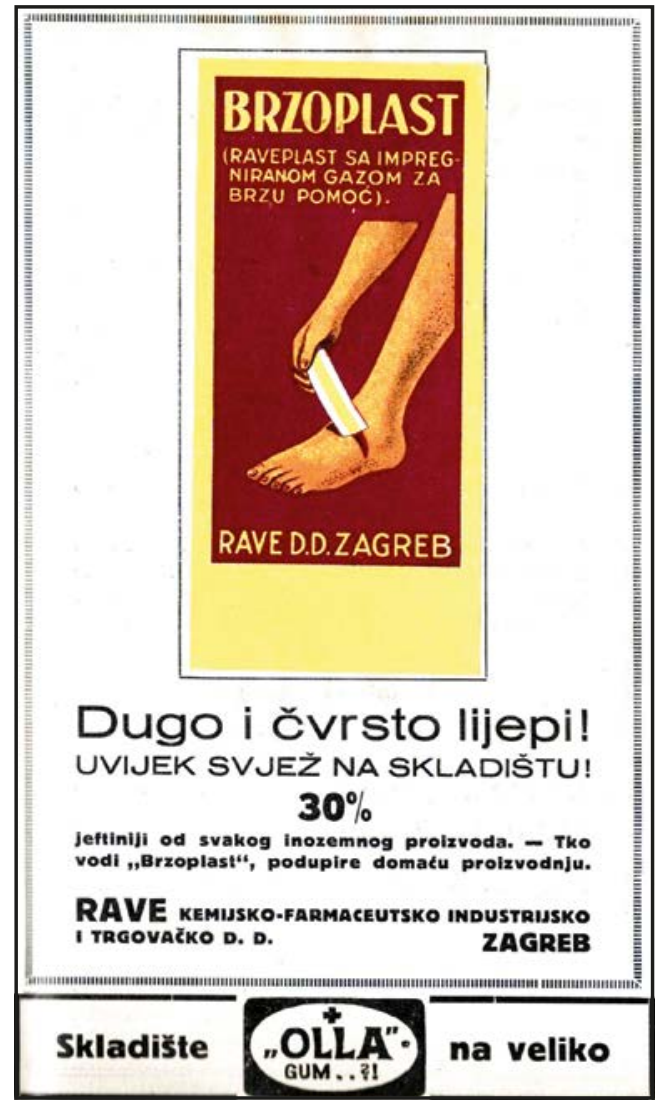

Slika 6. Reklama za Brzoplast. Farmaceutski vjesnik, I929.

$i$ sanitetske industrije. Tu smo najviše imali u vidu one grane proizvodnje za koju se potrebne sirovine dobivaju u zemlji $i$ koja je najpotrebnija u narodnoj odbrani. Ovamo spadaju sredstva za dezinfekciju rana, flasteri ljepljivi i ljekoviti, bez kojih se danas ne može zamisliti moderna kirurgija, zavojni materijal i bandaže. Bandaže smo još prošle godine uvažali isključivo iz inozemstva, dok u ovoj godini pretežnu potrebu pokrili smo vlastitom proizvodnjom, što znači jedan golem uspjeh. Razumljivo je da ćemo nastojati u tom pravcu, da postanemo što neodvisniji od inozemstva. Što više mi imamo nade, da će nam biti moguće naše proizvode eksportirati, jer gotovo sve, za ovu proizvodnju potrebne sirovine imamo u državi. ${ }^{43}$ Ostvarenje ovih ciljeva, međutim, nije bilo moguće bez potpore mjerodavnih tijela pa

42 HR-DAZG-940, Sudbeni stol u Zagrebu, Trgovački sud Zb 37/22 kutija 2298. Izvješće sa VII. redovite glavne skupštine, 11. svibnja 1929.

43 HR-DAZG-940, Sudbeni stol u Zagrebu, Trgovački sud Zb 37/22 kutija 2298. Godišnje izvješće o poslovanju tvrtke od 31. prosinca 1929. 
se ravnateljstvo Rave d.d. uzdaje u potporu grada u davanju pogonske snage, rasvjete, ukidanjem neopravdane gradske potrošarine te davanjem jeftinog ili besplatnog industrijskoga gradilišta. Vlasnici su bezuspješno pri gradskoj upravi lobirali i za osnutak industrijskog odbora. ${ }^{44} \mathrm{Klima}$, međutim, nije bila poticajna za razvoj industrije. Različita područja Jugoslavije u to su vrijeme bila opterećena različitim porezima. Član ravnateljskog vijeća Arnold Hunski stalno iznosi poteškoće s kojima se zagrebačka industrija i dioničko društvo Rave susreću. Predlaže ujednačenje cijena za gradsku potrošarinu na alkohol te za izradu jedinstvenog pravilnika za takse u čitavoj državi. Naime, zagrebački su industrijalci prema njegovu iskazu bili u težoj situaciji jer je u Zagrebu porez na promet bio dvostruko veći od državnog. Navodi da je $u$ mnogim mjestima gradska trošarina na alkohol niža od banovinske a tamo gdje je jednaka banovinskoj, daju industriji djelomične ili potpune oproste. Uslijed toga je vanjskim poduzećima moguće, da ne samo po cijeloj zemlji konkuriraju zagrebačkim industrijama, već i u samom Zagrebu. Slično je i sa taracovinom. Na pr. za fabrikaciju flastera uvažamo eksotične sirovine, koje su slobodne od državne uvozne carine, ali od gradske taracovine ne. ${ }^{45} \mathrm{Zbog}$ svekolikih nameta i za industriju nepoticajnog okruženja, u Zagrebu se već tada opaža i tendencija za iseljenjem industrije. ${ }^{46}$

Tijekom 1929. dolazi i do promjena u ravnateljstvu tvrtke. Iz ravnateljstva je izašao Desiderius Hoff, a na njegovo je mjesto došao Dragutin Vergles, ${ }^{47}$ dotadašnji član nadzornog odbora. Na mjesto člana nadzornog odbora, umjesto Josipa Hoffa, izabran je Viktor Eisenhut, a na mjesto Dragutina Verglesa dolazi Antun Hacker. ${ }^{48}$

44 HR-DAZG-940, Sudbeni stol u Zagrebu, Trgovački sud Zb 37/22 kutija 2298. Godišnje izvješće o poslovanju tvrtke od 31. prosinca 1929.

45 HR-DAZG-940, Sudbeni stol u Zagrebu, Trgovački sud Zb 37/22 kutija 2298. Zapisnik VIII. redovite glavne skupštine, 25. svibnja 1930.

46 Slična za zagrebačku industriju obeshrabrujuća tendencija ekonomske i porezne politike nastavit će se i u razdoblju 1935. - 1938. To je rezultiralo bijegom industrije s područja Savske banovine na područje Uprave grada Beograda koji nije imao banovinska davanja. U Zagrebu su davanja iznosila $25 \%$, a stopa prireza $40 \%$, što je bilo dvostruko više nego u Beogradu. Sve u svemu, opterećenje gospodarstva u Beogradu bilo je $60 \%$ manje, a trošarine o kojima govori i Hunski, koje su postojale na području Savske banovine, u Beogradu se nisu naplaćivale. Usporedi: Žebec Šilj, I. (2017), 50-51.

47 Oglas broj 43.465 gr. R 1922 ., u Zagrebu, 12. lipnja 1929. Narodne novine, 5.7.1929., 152, 8.

48 HR-DAZG-940, Sudbeni stol u Zagrebu, Trgovački sud Zb 37/22 kutija 2298. Dopis tvrtke Rave Kraljevskom sudbenom stolu, 12. lipnja 1929. 


\section{NA NOVOJ LOKACIJI}

Nepovoljne okolnosti vezane uz razvoj industrije ne mijenjaju se ni tijekom 1930. godine, koja je završila gubitkom u poslovanju zbog više razloga. Jedan od njih je bio i taj da je kartel ${ }^{49}$ veledrogerija obarao cijene koštanja i to nerijetko za cijene proizvoda domaće farmaceutske industrije. Tvornice su bile primorane na tako snižene cijene odobriti još $20 \%$ rabata jer toliko je kartel morao zaraditi. Hunski navodi da prema otvorenoj izjavi jednog otvorenog člana kartelirane veledrogerije, kartel ide za upropaštenjem domaće farmaceutske industrije. Ova navala kartela na domaću farmaceutsku industriju je vrlo ozbiljne naravi, jer kartel na monopoliziranim inozemnim farmaceutskim proizvodima, o čemu je već bilo govora u izvještaju ravnateljstva, zarađuje $25 \%$, a ovi monopolizirani proizvodi sačinjavaju pretežni dio prometa karteliranih drogerija. Uočivši domaće farmaceutske tvornice $i$ veledrogerije izvan kartela namjere kartela, stisnuli su redove, osnovavši posebnu sekciju domaće farmaceutske industrije u okrilju Saveza industrijalaca u Zagrebu sa svrhom, da se nadje način i putevi kojim bi se zapriječilo ovo presizanje kartela veledrogerija u samu bit farmaceutske industrije i uopće za promicanje $i$ čuvanje zajedničkih interesa. Borba kartela veledrogerija protiv industrije omogućena je i time, što većina članova uživaju kredite kod Narodne banke. Tako je konstatirano, da ovdašnja jedna veledrogerija uživa kredit kod Narodne banke u visini od $80 \%$ dioničke glavnice. ${ }^{50}$

Teškoće su proizlazile i iz činjenice da tvornica nije mogla doći do optimalnog prostora te i dalje posluje u unajmljenim prostorima $\mathrm{u}$ kojima je racionalan rad nemoguć jer se prostori nalaze u dvije različite ulice.${ }^{51}$ Budući da su se skladišta nalazila u samom središtu grada, a najamnina za prostor iznosila je 77.000 dinara, što je bila visoka svota, na skupštini 1930. predlaže se da taj iznos bude ulog za podizanje dugoročnog zajma za izgradnju vlastite zgrade. ${ }^{52}$ Već krajem iste godine upravi uspijeva povoljnom kupnjom namaknuti tvorničku zgradu u Vrbanićevoj 2 (danas Vrbanićeva ulica 28). ${ }^{53}$ Ta je jednokatna

49 Najrašireniji oblik poslovnog udruživanja industrijskih poduzeća koja proizvode iste proizvode bio je kartel. Međusobnim sporazumom ta su poduzeća određivala uvjete zajedničkog istupanja na tržištu s ciljem monopolističkog diktiranja uvjeta na području cijena i proizvodnje. Usporedi: Žebec Šilj, I. (2017), 255.

50 HR-DAZG-940, Sudbeni stol u Zagrebu, Trgovački sud Zb 37/22 kutija 2298. Izvješće od 29. svibnja 1931.

51 HR-DAZG-940, Sudbeni stol u Zagrebu, Trgovački sud Zb 37/22 kutija 2298. Izvješće od 13. ožujka 1923.

52 HR-DAZG-940, Sudbeni stol u Zagrebu, Trgovački sud Zb 37/22 kutija 2298. Zapisnik VIII. glavne skupštine Rave, 25. svibnja 1930.

53 HR-DAZG-940, Sudbeni stol u Zagrebu, Trgovački sud Zb 37/22 kutija 2298. Poslovni izvještaj na IX. glavnoj skupštini, 31. prosinca 1930. 
tvornička zgrada jednostavnog uličnog pročelja, locirana na prostranom zemljištu na istočnoj periferiji grada, bila izgrađena za potrebe Tvornice dvopeka Nada I922., ${ }^{54}$ a njezin projekt potpisuje građevinska tvrtka Simon i Ružinski. ${ }^{55}$ Program širenja grada prema istoku, iako zamišljen već regulacijskim planom grada I865., sustavnije se počeo provoditi tek nakon Prvoga svjetskog rata zalaganjem tvorca modernog Zagreba, gradonačelnika Vjekoslava Heinzela koji se I920. izborio za prihvat zaključka da će kroz deset godina biti oslobođene gradskog nameta sve novogradnje, prigradnje i nadogradnje. ${ }^{56} \mathrm{Za}$ sam projekt Tvornice dvopeka značajno je da je Heinzel omogućio iznimno povoljnu prodaju zemljišta na Zavrtnici (prostor omeđen Vrbanićevom, Tuškanovom i Banjavčićevom ulicom), čime je formiran kompleks koji se sastojao od nekoliko domaćih tvornica: Tvornica rublja d.d., Tvornica tinte, Tvornica cipela Frković i drug te Tvornica dvopeka Nada.

Kao preduvjet za dozvolu gradnje istaknuta je obaveza zapošljavanja isključivo domaće radne snage ${ }^{57}$ za čije je potrebe Tvornica dvopeka unutar tvorničkog kompleksa sagradila odvojene stambene zgrade za činovnike i radnike. Tvornica je djelovala svega nekoliko godina, a već I928. nalazimo ju u likvidaciji. ${ }^{58}$

Nakon kupnje tvorničkog kompleksa u Vrbanićevoj, tvrtka Rave krenula je u uređenje i dogradnju, koje samostalno provodi graditelj Makso Ružinski. Građevna dozvola za podignuće dijela novogradnje i uređenje tvornice kosmetskih i farmaceutskih preparata izdana je 15. svibnja I931., a slijedi ju uporabna dozvola 24. rujna I93I. godine. ${ }^{59}$ Međutim, pogoni i administracija poduzeća smješteni su u novoj zgradi već od kolovoza 1930. pa se krajem iste godine na Godišnjoj skupštini Rave izvještava o svim prednostima preseljenja: ...sve je na okupu, svrsishodno raspoređeno i nanovo organizirano, cijelo poslovanje se brže,

54 Nacrti za tvornički kompleks datirani su 1921. godinom. Građevnu dozvolu tvornica je dobila 20. ožujka 1922., a uporabnu dozvolu 15. veljače 1923. - HR-DAZG-4, Fond Gradskog poglavarstva Zagreb, Građevinski odsjek, Vrbanićeva 28.

55 Graditelji Đuro Simon i Maks Ružinski u međuratnom Zagrebu izveli su niz građevinskih objekata prosječne kvalitete, od prigradskih obiteljskih kuća do stambenih višekatnica u centru - vidi katalog objekata u: Kahle, Darko (2007), Stambene kuće novog građenja u sjevernim dijelovima Zagreba u razdoblju od 1928. do 1945. godine (doktorska disertacija), Zagreb; Arhitektonski fakultet Sveučilišta u Zagrebu.

56 Kolar Dimitrijević, Mira (1994), O zagrebačkom gospodarstveniku Vjekoslavu Heinzelu (1871.-1934.), Časopis za suvremenu povijest, 26 (2), 262.

57 Isto.

58 HR-DAZG-4, Fond Gradskog poglavarstva Zagreb, Građevinski odsjek, Vrbanićeva 28.

59 Isto. 
sigurnije i točnije odvija ${ }^{60}$. U sačuvanim planovima prizemlja i kata vidljiv je racionalan i praktičan raspored prostorija: u prizemlju su se nalazile mnogobrojne prostorije za pripremu robe i laboratoriji, a na katu prostori za pakiranje robe i veliko skladište, s odvojenim uredima.

U izvješću ravnateljstva za I930. godinu spominje se i potreba nabave automobila, s obzirom na to da je preseljenjem iz centruma na periferiju grada dostavljanje i dobavljanje u samom gradu po ljudima postalo nemoguće. Ali i ova nova stavka u troškovima pokazala se djelotvornom - prije je četiri do pet ljudi obavljalo dostavu pješice po gradu, a sada isti posao može obaviti samo jedan vozač. ${ }^{61}$

U popisu dioničara u to vrijeme također dolazi do izmjena. Uz Raca i Verglesa koji imaju svaki po rooo dionica, Arnold Hunski, Leopold Glaninger i Artur Gvozdanović posjeduju 500, Viktor Eisenhut i Vilko Kalmer 295, Ivan Gjurgjan 200, Paula Kovačić ıoo, Ivan Bahčić ıoo i Antun Hacker io dionica. ${ }^{62}$

\section{Marketing}

Rave d.d. je od samih početaka svoga poslovanja nazočan i na izložbama, pa tako i na Kemijsko-farmaceutskoj izložbi postavljenoj 4. listopada I934. tijekom trećeg Kongresa Federacije slavenskih apotekara na Zagrebačkom velesajmu. U osvrtu na izložbu navodi se da je Tvrtka Rave na ovoj izložbi pokazala svestranost svoga poslovanja $i$ ponovno nam dokazala, da i domaće naše firme mogu potpuno zadovoljiti svim potrebama naših apoteka ${ }^{63}$ (slika 7.). Iste godine Zdravstveni šematizam Kraljevine Jugoslavije navodi da Rave u vlastitoj proizvodnji ima farmaceutske čokolade, šećeriće, specijalitete, sterilne injekcije, pilule, tablete, ljepive i medicinske meleme, bandaže, sanitarnu robu, parfemske i kozmetičke preparate. U skladištu na veliko Rave d.d. raspolaže drogama, kemikalijama, eterskim uljima, esencijama, kirurškom, gumenom i higijenskom robom, sanitetskim materijalom, uređajima, priborom za ljekarne i laboratorije. Šematizam ju navodi kao jedinu domaću tvornicu flastera (Raveplast i Brzoplast). ${ }^{64}$ Oglasi se objavljuju i na stranicama farmaceutskih

60 HR-DAZG-940, Sudbeni stol u Zagrebu, Trgovački sud Zb 37/22 kutija 2298. Poslovni izvještaj na X. glavnoj skupštini, 31. prosinca 1930.

61 Isto.

62 HR-DAZG-940, Sudbeni stol u Zagrebu, Trgovački sud Zb 37/22 kutija 2298. Zapisnik IX. redovite glavne skupštine, 29. svibnja 1931.

63 Anonimno (1934), Kemijsko-farmaceutska izložba na Zagrebačkom Zboru u Zagrebu, Apotekarski vjesnik, 16(20),1074.

64 Anonimno (1934). Zdravstveni šematizam za Kraljevinu Jugoslaviju, knjiga 1. Zagreb; Ćirilometodski zavod u Zagrebu, 814. 


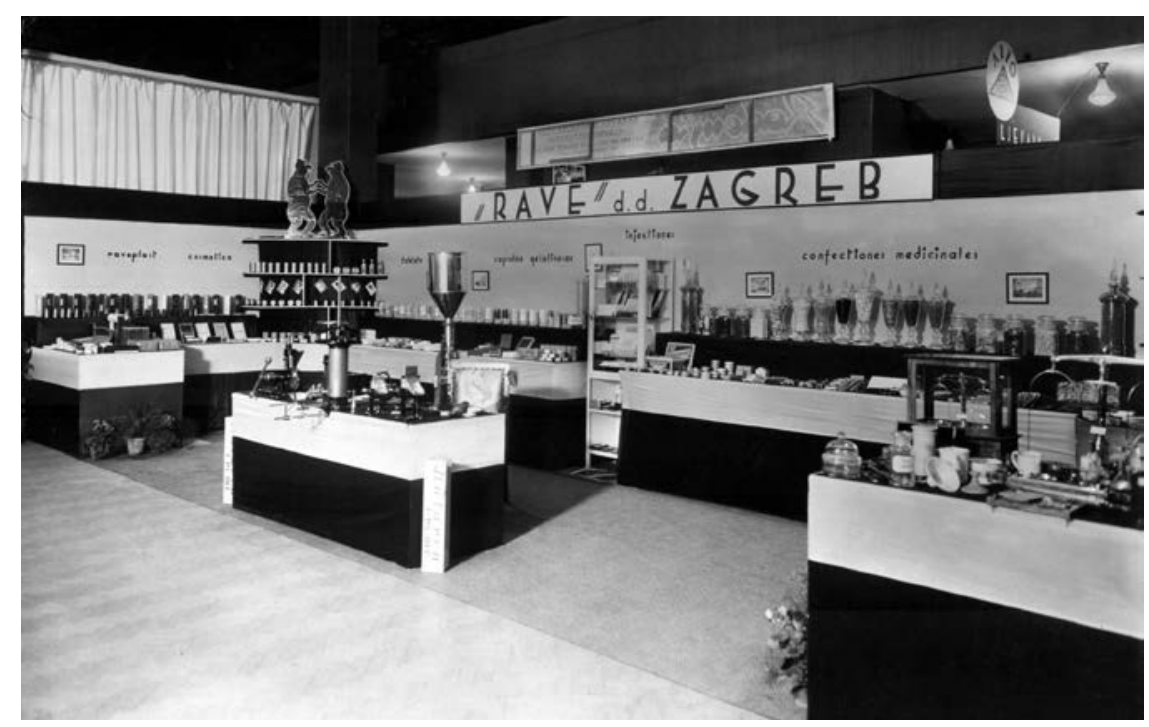

Slika 7. Rave na Kemijsko-farmaceutskoj izložbi I934., Zagrebački velesajam. OPMZ-HAZU

godišnjaka, almanaha za farmaciju i kemiju, kodeksa specijaliteta, na stranicama strukovnih gasila. U vrijeme kada joj je proizvodnja u ekspanziji, promidžbeni prostor koji otvaraju stručne publikacije postaje ipak premalen za sve proizvode koji se žele oglasiti te se javlja potreba za intenzivnijom suradnjom i komunikacijom sa strukom (ljekarnicima i liječnicima) preko kojih se roba distribuira. Tvrtka stoga I934. kreće u izdavanje vlastitog časopisa - mjesečnika pod nazivom Medicinsko-farmaceutska pošta.

Izdavanje vlastitih časopisa farmaceutskih tvrtki nije u to vrijeme bila novost. Jake europske tvrtke već su utrle taj put na međunarodnoj razini, a razvojem domaće farmaceutske industrije između dvaju svjetskih ratova i otvaranjem brojnih zastupstava inozemnih farmaceutskih tvrtki ta se praksa počinje primjenjivati i na našem području. Svoja glasila izdaju tada vodeće farmaceutske tvrtke poput kemijsko-farmaceutske tvornice Kemika, Jugefa K. D. i kemijsko-farmaceutske tvornice Kaštel d.d. ${ }^{65}$ Pokretanje časopisa Medicinsko-farmaceutska pošta povećalo je financijske iznose za oglase. Trošak izdavanja časopisa iznosio je visokih 15.000 dinara mjesečno pa stoga

65 Časopis Medicus farmaceutske tvrtke Kaštel d.d. jedini je među nabrojenima zadržao kontinuitet s povremenim prekidima u izlaženju (1941. - 1954.) i promjenom imena u Saopćenja (1954. - 1989.) te i sada izlazi pod nekadašnjim nazivom Medicus. Dugački, Vladimir (2002), O 70. obljetnici časopisa „Medicus“, Medicus 11(2), 291-294. 
ravnateljstvo tvrtke napušta druge tipove oglašavanja. ${ }^{66} \mathrm{U}$ izvješću Glavne skupštine navodi se da su već vidljivi dobri rezultati zbog djelovanja reklame koja se preko časopisa provodi. ${ }^{67}$

Od samog početka rada tvornice, pa tako i na stranicama Medicinskofarmaceutske pošte, ističe se da je riječ o isključivo domaćem $i$ narodnom poduzeću koje sa najvećom simpatijom pratilo napredak naše domaće industrije jer vjeruje da je svaki njen napredak od opće narodne koristi. ${ }^{68} \mathrm{U}$ tom smjeru Rave nastoji poduprijeti i druga poduzeća sa zajedničkim ciljem osamostaljenja od industrije i trgovine. Kao primjer navodi potporu našoj prvoj tvornici laboratorijskog posuđa od koje je preuzelo samoprodaju domaćega laboratorijskog stakla. ${ }^{69} \mathrm{U}$ promet uključuje i znatno osuvremenjenu ljekarničku staklenu ambalažu koja sadrži medicinske boce s bakelitnim čepom u svim veličinama, bočice za jodnu tinkturu, Remco bocu za mjerenje kapi, lončiće za masti i sl., pa i te proizvode redovito oglašava.

Sveukupan marketinški segment posla odnosi tvornici i znatan dio sredstava pa se je primjerice na oglase i reklame u I932. izdvajalo II5.0I8.6I din., odnosno 6,5 \% ukupnih troškova. Godine i935. izdvojeno je rekordnih 213.003,95 din., odnosno io \% ukupnih troškova, nakon čega ova svota počinje postupno opadati: I937. ukupno I43.7II,70 din. (6,6 \%); u I938. godini I27.453.I5 din (5,8 \%). U I940. izdvojeno je I76.78r din., odnosno 4,8 \%, a tijekom ratne I94I. svota koja se izdvaja za oglase smanjuje se na 60.4IO.50 din., što je svega I,I \% ukupnih troškova. Vrhunac smanjenja ovoga troška događa se I943., kada svota od 60.4Io kuna iznosi $45 \%$ prošlogodišnjeg izdvajanja, odnosno samo o,4 \% cjelokupnog troška. Kroz segment izdvajanja za reklamu na određeni se način može pratiti i uspješnost poslovanja tvornice, ali i kontekst vremena u kojemu posluje. Od samog početka dioničko društvo zapošljava trgovačke putnike za rad na terenu te isprva jedna, a potom tri osobe obilaze liječnike i prezentiraju proizvode.

Reklama je zasigurno pridonosila boljem plasmanu na tržištu i porastu prodaje, no opće nepovoljne prilike u zemlji i inozemstvu nisu ni tijekom I935. olakšavale poslovanje. Tome je pridonio pad cijena, slabiji turistički promet,

66 Primjerice, napušteno je putovanje po jugoistočnom dijelu države. Usporedi: Anonimno (1935), Izvještaj ravnateljstva, Medicinsko-farmaceutska pošta, 2(5), 158.

67 HR-DAZG-940, Sudbeni stol u Zagrebu, Trgovački sud Zb 37/22 kutija 2298. Izvješće za 1934. godinu, 31. prosinca 1934.

68 Usporedi: Anonimno (1935), Domaće laboratorijsko posuđe, Medicinsko-farmaceutska pošta, 1(12), 366-368

69 Staklo je imalo vodeni znak tvornice Rave, tj. 2 medvjeda. Usporedi: Anonimno (1935), Domaće laboratorijsko posuđe, Medicinsko-farmaceutska pošta, 1(12), 366-368. 
nesigurna međunarodna situacija i sankcije te slabljenje kupovne moći srednjega sloja populacije. Dodatno su opterećenje tvornice u toj godini bili visoki krediti, a iznos plaćenih kamata bio je 86.026.69 dinara. Poslovanje je bilo otežano i zbog visokih poreza i prireza koja je u I935. iznosila I23.660.50 dinara, za razliku od prethodne godine, kada je u tu svrhu tvornica uplatila 38.976.37 dinara. Dobitak u I935. godini iznosio je 68.534.20 dinara.

\section{RATNE GODINE}

Godišnja izvješća Rave d.d. dobar su pokazatelj kompleksnog i zahtjevnog poslovanja veledrogerija u tom razdoblju. Poslovanje je podrazumijevalo visoke izdatke od održavanja strojeva i režija te poreza, visokim su izdatcima pridonosili socijalni doprinosi, osiguranja te radničke plaće i nadnice. Zarade u tim okolnostima nisu bile visoke, kako se često pretpostavljalo, na što se osvrće i ravnateljstvo Rave u svom izvješću: ...naši direktori rade kao $i$ svaki drugi namještenik $i$ te kako intenzivno... U našem slučaju iznos od Din. 386.875 isplaćen je na I5 stalnih namještenika našeg poduzeća kroz jednu godinu dana. U tom iznosu uključene su i plaće trojice direktora. ${ }^{70}$

U I940. promet je porastao za 20\%. Osim porasta cijena, na povišenje prometa utjecalo je i uvećanje vlastitih sredstava povišenjem dioničke glavnice na 2.000.000 dinara. S pričuvnom zakladom od I00.000 i stalnim zajmovima kod Narodne banke i drugih banaka u iznosu od I.657.082 dinara, prometna glavnica iznosi 3.757.082 dinara. Povoljna okolnost je bila i ta da je velik broj skladišta inozemnih tvornica bio smješten u Zagrebu, što je znatno olakšavalo nabavu robe. Problem su i dalje dužnici u koje spadaju i javne ustanove.

Porast proizvodnje tvrtke dovodi do neizbježnog nedostatka prostora za skladištenje robe. Stoga se u unutarnjem dvorištu tvornice i937. gradi prizemno spremište sa šest prostorija. ${ }^{71} \mathrm{Ni}$ taj prostor ubrzo neće zadovoljavati sve potrebe pa ravnateljstvo odlučuje da će se proizvodnja preseliti dalje izvan grada. Ističu se sigurnosni, higijenski i društveni razlozi za preseljenje, kako bi se radnicima poboljšali uvjeti za rad. U tu je svrhu kupljeno zemljište od 2 I77 hvati, a u I94I. godini bilo je planirano pristupiti gradnji. ${ }^{72}$ Zgrada, međutim, nije izgrađena jer su građevinski materijal i radna snaga višestruko poskupjeli pa tvornica do kraja rata ostaje $\mathrm{u}$ istim prostorima $\mathrm{u}$ Vrbanićevoj

70 Anonimno (1935), Izvještaj ravnateljstva, Medicinsko-farmaceutska pošta, 2 (5), 159.

71 HR-DAZG-4, Fond Gradskog poglavarstva Zagreb, Građevinski odsjek, Vrbanićeva 28. Građevinska dozvola za skladište 23. srpnja 1937., uporabna dozvola 23. veljače 1938.

72 HR-DAZG-940, Sudbeni stol u Zagrebu Trgovački sud Zb 37/22 kutija 2298. Izvještaj na Glavnoj skupštini, 31. prosinca 1941. 
ulici. Porast cijena u graditeljstvu nije pratio i porast cijena lijekova pa je farmaceutska industrija, čije je cijene diktiralo i kontroliralo Ministarstvo zdravstva, zaostajala za drugim sektorima proizvodnje.

Zaključkom 20. glavne skupštine održane 29. kolovoza 1942. mijenjaju se pravila Društva: ime je promijenjeno u "Rave“ kemijsko farmaceutsko veleobrtno i trgovačko dioničko društvo Zagreb. Temeljna dionička glavnica je znatno povećana i iznosi 10.000.000 kuna, ${ }^{73}$ a razdijeljena je u 40.000 komada dionica po 250 kuna nominale. ${ }^{74} \mathrm{U}$ sklopu obilježavanja 25 . obljetnice postojanja tvrtke, ${ }^{75}$ unatoč tome što poduzeće već uplaćuje dio u Mirovinski fond i Radničko osiguranje, donijeta je i odluka o osnutku pričuve za potpornu zakladu odsluženih suradnika. U skladu s tim, u izvješću skupštine ističe se da uprava osijeća da postupa u duhu novih družtvovnih načela, ako za svoje suradnike stvori mogućnost dodatnog osiguranja za nemoć i starost. U tu je svrhu uplaćeno 250.000 kuna. $^{76}$

\section{Nakon Drugoga svjetskog Rata}

Po završetku Drugoga svjetskog rata, 17. kolovoza 1946. nakon duge i teške bolesti u 56 . godini u Zagrebu umire Dragutin Vergles. ${ }^{77}$ Osam godina poslije, Io. listopada 1954., u 66. godini umire i Stjepan Rac. ${ }^{78} \mathrm{U}$ istom broju Farmaceutskog glasnika, u kojem izlazi vijest o Racovoj smrti, izlazi i nepotpisani nekrolog u kojemu se navodi da je Rac, uz Verglesa, osnovao Rave te da je u praksi dokazao kako se može proširiti polje rada farmacenta $i$ povratiti ono, što je bilo izgubljeno za farmaceute, a zapravo je poteklo iz farmacije: kozmetika. Samo je farmaceut mogao dati punu garanciju za kvalitet i neškodljivost ovih pripravaka. ${ }^{79}$

Tvrtka Rave d.d. nastala iz istraživanja i razvoja čiji su osnivači bili farmaceuti koji su krenuli iz laboratorija, a potom započeli masovnu proizvodnju, nacionalizirana je 1947. te je na temelju članka 21. Osnovnog zakona o državnim privrednim poduzećima i točke 2. Naredbe Vlade FNRJ o prijenosu postrojenja i spajanju nacionaliziranih poduzeća s državnim privrednim poduzećima doneseno rješenje o spajanju $D r$. Wander d.d. tvornice farmaceutskih

73 Povišenje dioničke glavnice odobrilo je Ministarstvo za obrt, veleobrt i trgovinu, Odjel za gospodarsku politiku svojom odlukom broj 88.434 od 5. rujna 1942.

HR-DAZG-940, Sudbeni stol u Zagrebu Trgovački sud Zb 37/22 kutija 2298.

Kontinuitet tvrtke ravnateljstvo vodi od osnutka laboratorija dakle od 1918. godine.

HR-DAZG-940, Sudbeni stol u Zagrebu Trgovački sud Zb 37/22 kutija 2298. Zapisnik glavne godišnje skupštine održane 31. prosinca 1943.

Anonimno (1946), Umrli,Farmaceutski glasnik, 2(9), 399.

Anonimno (1954), Umrli,Farmaceutski glasnik, 10(10), 454.

Anonimno (1954), Osobne vijesti,Farmaceutski glasnik, 10 (11), 492. 
i dijetetičkih preparata i Rave - kemijsko farmaceutsko industrijskog dioničkog društva Zagreb, s privrednim poduzećem općedržavnog značaja Neva - tvornica higijensko kozmetičkih sredstava u Zagrebu. ${ }^{80}$ Rave je tako 26. ožujka i948. pripojena Nevi - tvornici higijensko-kozmetičkih sredstava, pravnoj nasljednici tvrtke Beiersdorf društvo Zagreb. ${ }^{81}$ Direktorom tvornice imenovan je Krešo Topolšak. ${ }^{82}$ Neva je već tijekom I947. preuzela nekretnine koje su pripadale tvrtki Rave i započela adaptaciju prizemlja i prvog kata ulične zgrade tvorničkog kompleksa u Vrbanićevoj ulici $28 .{ }^{83}$

U okviru suradnje s Beiersdorfom, koja je potrajala više od pedeset godina, Nevi je na samome početku povjerena ekskluzivna proizvodnja i distribucija Beiersdorfovih proizvoda za tržište Jugoslavije, ${ }^{84}$ a I960-ih tvrtka počinje s proizvodnjom i drugih poznatih zapadnoeuropskih brendova: Helene Winterstein, L'Oreal i Juvena. Istodobno, od početka I950-ih, tvrtka razvija i vlastiti asortiman proizvoda, obnavljajući pritom kategoriju kozmetičkih proizvoda koja podsjeća na predratni Ravin asortiman (Nevasol, kreme Neva i Neva Baby te voda za usta Nevadont). ${ }^{85}$ Do danas na tržištu postoje Nevini proizvodi Plidenta i Rosal, razvijeni I980-ih godina.

\section{ZAKLJUČAK}

Laboratorij iz kojega je osnovano dioničko društvo Rave nastaje u vremenima nakon Prvoga svjetskog rata kada se težilo razvoju domaće industrije koja bi služila nacionalnim interesima. Po svojoj orijentaciji i širokom rasponu proizvodnje i zastupstva njegov sljednik, Dioničko društvo Rave, postaje na našim prostorima prva tvrtka u proizvodnji medicinskih šećerića, bandaža, flastera, a nastojeći sudjelovati u što snažnijoj izgradnji domaće industrije i osamostaljenja u odnosu na strane tvrtke pokreće proizvodnju ljekovitih melema. Kao važnom segmentu svoga poslovanja ova tvornica osobitu pozornost posvećuje marketingu, sudjelujući pritom u razvoju farmaceutskog oglašavanja i promidžbe.

80 Rješenje od 2. svibnja 1947. potpisuje predsjednik Komiteta za zaštitu narodnog zdravlja, ministar bez resora dr. Dmitar Nestorović i predsjednik Vlade FNRJ i ministar narodne odbrane, maršal Jugoslavije Josip Broz Tito. HR-DAZ-84, Sudbeni stol u Zagrebu. Trgovački sud. Fi-3101-33-kut. 2576. Trgovački i zadružni registar - brisanja, Narodne novine, 1948., br. 46, str. 11.

82 HR-DAZG-84, Sudbeni stol u Zagrebu. Trgovački sud. Fi-3101-33-kut. 2576. Rješenje Komiteta za zaštitu narodnog zdravlja Vlade FNRJ br.1568 od 3.lipnja 1947.

83 HR-DAZG-4, Fond Gradskog poglavarstva Zagreb, Građevinski odsjek, Vrbanićeva 28.

84 Reckendrees, Alfred (2018). Beiersdorf: The Company behind the Brands NIVEA, tesa, Hansaplast $8 \mathrm{Co}$, München; C.H.Beck.

85 Vlajo, Koraljka (2013). Marijina industrija ljepote - Marija Kalentić $i$ "Neva" dizajn ambalaže 1963-1985. (katalog izložbe), Zagreb; Muzej za umjetnost i obrt, 35-36. 
Dokumentacija i gradivo koje razotkriva rad i razvoj ove tvrtke ukazuje istodobno na razdoblje kada se u smjeni nekoliko društveno-političkih sustava, u iznimno nepoticajnoj poduzetničkoj klimi u Hrvatskoj stvarala nacionalna farmaceutska industrija. Kao važan motiv svoga poslovanja tvornica ističe osamostaljivanje od industrije, nacionalna obilježja svoga poslovanja i poticanje suradnje s mladom domaćom industrijom. U skladu s tim Rave sudjeluje u izgradnji i razvoju domaće farmaceutske proizvodnje, domaćeg tržišta, poticanju razvoja suvremene industrije i borbi za povoljnije uvjete svoga poslovanja. Stoga je njezina, do sada zanemarivana povijest važan segment hrvatske farmaceutske prošlosti, ali i industrijskog i gospodarskog razvoja šire regije.

\section{IZVORI}

1. Odsjek za povijest medicinskih znanosti HAZU, OPMZ HAZU. Fond ljekarništvo / Ljekarna Salvatoru. Kartoteka ljekarnika: Mr. Stjepan Rac

2. Odsjek za povijest medicinskih znanosti HAZU, OPMZ HAZU. Fond ljekarništvo / Ljekarna Salvatoru. Kartoteka ljekarnika: Mr. Dragutin (Carol) Vergles

3. Državni arhiv u Zagrebu, HR-DAZG-940, Sudbeni stol u Zagrebu, Trgovački sud, Zb 37/22 kutija 2298.

4. Državni arhiv u Zagrebu, HR DAZG-84, Sudbeni stol u Zagrebu. Trgovački sud. Fi-3101-33-kut. 2576.

5. Državni arhiv u Zagrebu, HR-DAZG-4, Fond Gradskog poglavarstva Zagreb, Građevinski odsjek, Vrbanićeva 28.

\section{LITERATURA}

1. Aničić, Ema (2014). R.I.P. - riječka industrijska priča. Rijeka; Muzej grada Rijeke.

2. Anonimno (1922), Trgovačke i industrijalne vijesti. Rave kemijsko-farmaceutsko industrijsko i trgovačko D.D. Zagreb, Vjesnik ljekarnika,4 (3), 90-1.

3. Anonimno (1922), Strukovne vijesti. Naša kemijska industrija i sirovine za nju, Vjesnik ljekarnika, 4 (4), 122-3.

4. Anonimno (1922), Prikazivanje Merckovog filma u Zagrebu, Vjesnik ljekarnika, 4 (12), 330-1.

5. Anonimno (1924), Preseljenje drogerije, Vjesnik ljekarnika, 6 (4), 160.

6. Anonimno (1924), Medicinsko-farmaceutska izložba u Zagrebu, Vjesnik ljekarnika, 6, 495.

7. Anonimno (1924), Trgovačke vijesti. Novi cjenik, Vjesnik ljekarnika, 6, 395.

8. Anonimno (1926), Razne vijesti. Stota obljetnica ljekarne Salvatoru u Zagrebu, Vjesnik ljekarnika, 8, 616-17. 
9. Anonimno (1926), Zabrana oglašavanja lijekova i farmaceutskih preparata, Vjesnik ljekarnika, 8, 42.

10. Anonimno (1926), Razne vijesti. 40 godišnji jubileum tvornice gume Vulkan, Vjesnik ljekarnika, 8, 617.

11. Anonimno (1929), Rave Kemijsko-farmaceutsko industrijsko i trgovačko d.d., Zagreb, Farmaceutski vjesnik, 19 (poseban broj), 48.

12. Anonimno (1934), Kemijsko-farmaceutska izložba na Zagrebačkom Zboru u Zagrebu, Apotekarski vjesnik, 16 (20), 1074.

13. Anonimno (1934). Zdravstveni šematizam za Kraljevinu Jugoslaviju, knjiga 1. Zagreb; Ćirilometodski zavod u Zagrebu, 814.

14. Anonimno (1935), Domaće laboratorijsko posuđe, Medicinsko-farmaceutska pošta, 1 (12), 366-368.

15. Anonimno (1935), Izvještaj ravnateljstva, Medicinsko-faramaceutska pošta, 2 (5), 158.

16. Anonimno (1941), Kaštel tvornica kemijsko-farmaceutskih proizvoda d.d. (prigodom 20. godišnjice opstanka), Medicus 3 (5), 246-7

17. Anonimno (1946), Umrli, Farmaceutski glasnik, 2 (9), 399.

18. Anonimno (1954), Umrli, Farmaceutski glasnik, 10 (10), 454.

19. Anonimno (1954), Osobne vijesti, Farmaceutski glasnik, 10 (11), 492.

20. Anonimno (1961), 40 godina, Saopćenja, 4 (5), 206-10.

21. Baković, Vladimir (1971), Razvoj jugoslavenske farmaceutske industrije, Saopćenja 14 (1), 53-8.

22. Baković, Vladimir (1981), Osvrt na značajne obljetnice u SOUR Pliva u 1981. godini, Saopćenja 27 (2), 171-81.

23. Ćapeta, Antun ed., (1996), Povjesnica Plive, Zagreb: Pliva d.d.

24. Dugački, Vladimir (2002), O 70. obljetnici časopisa „Medicus“, Medicus 11(2), 291-294.

25. Fatović-Ferenčić, Stella, Brkić Midžić, Silvija (2016). Kaštel na vrhuncu: oglašavanje i ambalaža lijekova tvornice Kaštel u Zagrebu 1930-ih i 1940-ih, Zagreb; HAZU, Hrvatski muzej medicine i farmacije.

26. Fatović-Ferenčić, Stella, Brkić Midžić, Silvija (2018). Početci i strategije marketinga tvornice Kaštel d.d. (1920.-1945.), Medicus, 27 (2), 211-222.

27. Kahle, Darko (2007), Stambene kuće novog građenja u sjevernim dijelovima Zagreba u razdoblju od 1928. do 1945. godine (doktorska disertacija), Zagreb; Arhitektonski fakultet Sveučilišta u Zagrebu.

28. Klinar, Ivana, Kolumbić Lakoš, Adela, Kovačić, Dražen, Matrapazovski Kukuruzović, Mirjana (2018), SUMAMED 30 godina - Kako je počela promocija PLIVINA originalnog antibiotika?, Medicus 27 (2), 223-230. 
29. Kolar Dimitrijević, Mira (1994), O zagrebačkom gospodarstveniku Vjekoslavu Heinzelu (1871.-1934.), Časopis za suvremenu povijest, 26 (2), 262.

30. Kujundžić, Nikola, (2012). Spomenica u povodu 130. obljetnice nastave farmacije 1882-2012. Zagreb; Farmaceutsko-biokemijski fakultet Sveučilišta u Zagrebu.

31. N. I. (1922), Zagrebački zbor i farmaceutska industrija, Vjesnik ljekarnika, 4 (8), 231-234.

32. Oglas broj 43.465 gr. R 1922 ., u Zagrebu 12. lipnja 1929. Narodne novine, 5. 7. 1929., 152,8 .

33. Reklama za Formosal (1923), Virovitičan, 40, 3.

34. Reklama Rave laboratorija (1922). Aesculap almanah za farmaciju i kemiju, 2, bez paginacije.

35. Ščrbašić, Mira (1974), Tradicija se nastavlja - izazov budućnosti, u: Keros, Predrag ed., Zbornik liječnika Hrvatske 1874-1974, Zagreb: Zbor liječnika Hrvatske. 1974, 299-306.

36. Trkulja, Milica (2008), Alga, u: Dubrović, Edvin ed., Reklama u Rijeci 1890-1940. Rijeka: Muzej grada Rijeke. 2008, 38-43.

37. Uredništvo (1929), Predgovor Industrijskom broju, Farmaceutski vjesnik, 19 (poseban broj), 1-3.

38. Žebec Šilj, Ivana (2017). Zagrebačka industrija 1935.-1939 u kontekstu međuratnog gospodarskog razdoblja. Zagreb; Institut Ivo Pilar.

39. Vlajo, Koraljka (2013). Marijina industrija ljepote-Marija Kalentić $i$ "Neva" dizajn ambalaže 1963-1985. (katalog izložbe), Zagreb; Muzej za umjetnost i obrt.

\section{SUMMARY}

The paper presents the development and business of the chemical-pharmaceutical factory Rave PLC, founded in Zagreb in 1922. Based on archival and building documentation, professional and daily newspapers, and promotional material, the formation of the factory complex in the Zagreb industrial zone was reconstructed, its marketing strategy and its impact on the development of domestic drug production and hygiene and sanitary necessities were presented. As an important motive for its operations, the factory emphasized industrial independence, the national features of its business and the promotion of cooperation with young domestic industry. In accordance with the above-mentioned text, Rave PLC participates in the construction and development of domestic pharmaceutical production and market, encouraging the development of modern industry and struggle for more favourable conditions of its business. Its unprecedented history is an important segment of our pharmaceutical past, but also an indispensable element of knowing the industrial development of the wider region. This segment of the beginnings of pharmaceutical manufacturing is essential in knowing the origins of entrepreneurship in our region as a significant element in raising awareness of national production, development and identity.

Keywords: Rave PLC, pharmaceutical industry, industrial heritage, 2oth century, Croatia 